7-12-1968

\title{
Actomyosin-like protein isolated from mammalian brain
}

Donald Dudley Clarke PhD

Fordham University, clarke@fordham.edu

S. Berl

Columbia University

S. Puszkin

Columbia University

Elena Puszkin

Mount Sinai School of Medicine

Follow this and additional works at: https://fordham.bepress.com/classics_facultypubs

Part of the Organic Chemistry Commons

\section{Recommended Citation}

Clarke, Donald Dudley PhD; Berl, S.; Puszkin, S.; and Puszkin, Elena, "Actomyosin-like protein isolated from mammalian brain" (1968). Faculty Publications. 4.

https://fordham.bepress.com/classics_facultypubs/4 


\section{Actomyosin-Like Protein Isolated from Mammalian Brain}

Abstract. A protein with characteristics similar to actomyosin has been isolated from whole brain of rat and cat. It is soluble in 0.6 molar potassium chloride and insoluble in 0.1 molar potassium chloride. It superprecipitates with magnesium ions and adenosine triphosphate. It has adenosine triphosphatase activity stimulated by either magnesium or calcium ions. Both superprecipitation and adenosine triphosphatase activity are inhibited by $\mathrm{p}$-chloromercuribenzoate and Mersalyl but not by ouabain.

In general, two categories of adenosine triphosphatase have been described based on the cations required for activity. For one group $\mathrm{Mg}^{2+}$ or $\mathrm{Ca}^{2+}$ is required; for the other, in addition to $\mathrm{Mg}^{2+}, \mathrm{Na}^{+}$and $\mathrm{K}^{+}$are required for maximum enzyme activity. The $\left(\mathrm{Na}^{+}\right.$ $+\mathrm{K}^{+}$)-activated enzyme systems, which function in active transport of $\mathrm{Na}^{+}$and $\mathrm{K}^{+}$across cell membranes, have been reviewed by Skou (1). The biochemical and physiological significance of the $\mathrm{Ca}^{2+}$ - or $\mathrm{Mg}^{2+}$-activated enzyme systems are less clear except as related to muscle contraction.

Libet (2) in his studies of $\mathrm{Ca}^{2+}$-activated adenosine triphosphatase activity of squid giant axon first suggested that proteins similar to that of the myosin system in muscle may be associated with the conduction of nerve impulses; such proteins would permit permeability changes in the membrane dependent upon structural changes. Bowler and Duncan (3) also suggested that contractile adenosine triphosphatases are probably responsible for the control of excitation in nerve and muscle cells. They believe that these enzymes are responsible for the control of passive permeability of excitable cells and possibly of all cells. Germain and Proulx and separately Kadota et al. (4) described $\mathrm{Mg}^{2+}$ - or $\mathrm{Ca}^{2+}$-stimulated activity in isolated synaptic vesicles of rat brain. The former investigators suggested that it functions in the storage and release of acetylcholine.

We now describe the isolation of a $\mathrm{Mg}^{2+}$ - or $\mathrm{Ca}^{2+}$-activated adenosine triphosphatase from whole brain of the rat and cat; this enzyme has properties similar to those of muscle actomyosin.

Brain protein was extracted by a modification of the procedure usually used for the extraction of actomyosin from muscle (5). Whole brains of rat or cat were cleansed of superficial blood vessels and washed with saline at $0^{\circ} \mathrm{C}$. The organs were homogenized with three volumes of $0.6 \mathrm{M} \mathrm{KCl}$ in a bicarbonate buffer at $p \mathrm{H} 8.2$ (Weber-Edsall solution) for 30 to 45 minutes at $0^{\circ} \mathrm{C}$. The homogenate was kept at $0^{\circ} \mathrm{C}$ for 16 hours and then centrifuged for 1 hour at $60,000 \mathrm{~g}$. The clear supernatant extract was diluted with glass-distilled water at $0^{\circ} \mathrm{C}$ to lower the ionic strength was brought to 6.3 by the addition of $0.125 M$ acetate buffer, $p \mathrm{H}$ 4.9. After standing for 1 hour the fine precipitate which developed was separated by centrifugation at $12,000 \mathrm{~g}$ for 5 minutes. The precipitate was dissolved in tris- $\mathrm{HCl}$ buffer $[0.05 M$ tris(hydroxymethyl)aminomethane, $0.6 M \mathrm{KCl}, p \mathrm{H}$ adjusted to 7.2 with $0.1 \mathrm{~N} \mathrm{HCl}$ ] and again precipitated by dilution of the $\mathrm{KCl}$ to 0.1 mole/liter with water. After a second reprecipitation the supernatant fluid of the $\mathrm{KCl}$ to $0.1 \mathrm{~mole} / \mathrm{liter}$. The $p \mathrm{H}$ contained only trace amounts of protein (6). The ratio of the readings at $280 \mathrm{~nm}$ and $260 \mathrm{~nm}$ of the protein dissolved in tris- $\mathrm{HCl}$ buffer indicated that approximately 6.5 percent nucleic acids may be present (7). The reprecipitated protein constituted approximately 1 to 2 percent of the total brain protein.

Szent-Györgyi (8) considers superprecipitation as characteristic of the contractile nature of actomyosin. The protein isolated from brain showed such characteristics (Fig. 1). In $0.1 M \mathrm{KCl}$, $10^{-3} M$ tris- $\mathrm{HCl}$ buffer ( $\left.p \mathrm{H} 7.2\right)$, the addition of both $3 \times 10^{-3} \mathrm{M} \mathrm{MgSO}_{4}$ and $4 \times 10^{-3} M$ adenosine triphosphate (ATP) caused the protein to form a dense granular precipitate which settled rapidly to the bottom of the tube. Without ATP $\mathrm{Mg}^{2+}$ did not have such an effect; ATP alone resulted in some precipitation probably because $\mathrm{Mg}^{2+}$ was already present in the protein. The superprecipitation was inhibited by previous incubation of the protein solution at $37^{\circ} \mathrm{C}$ for 5 minutes with sulfhydrylblocking agents such as p-chloromercuribenzoate $\left(10^{-2}\right.$ mole/liter $)$ or Mersalyl (10-3 mole/liter) (9); it was not

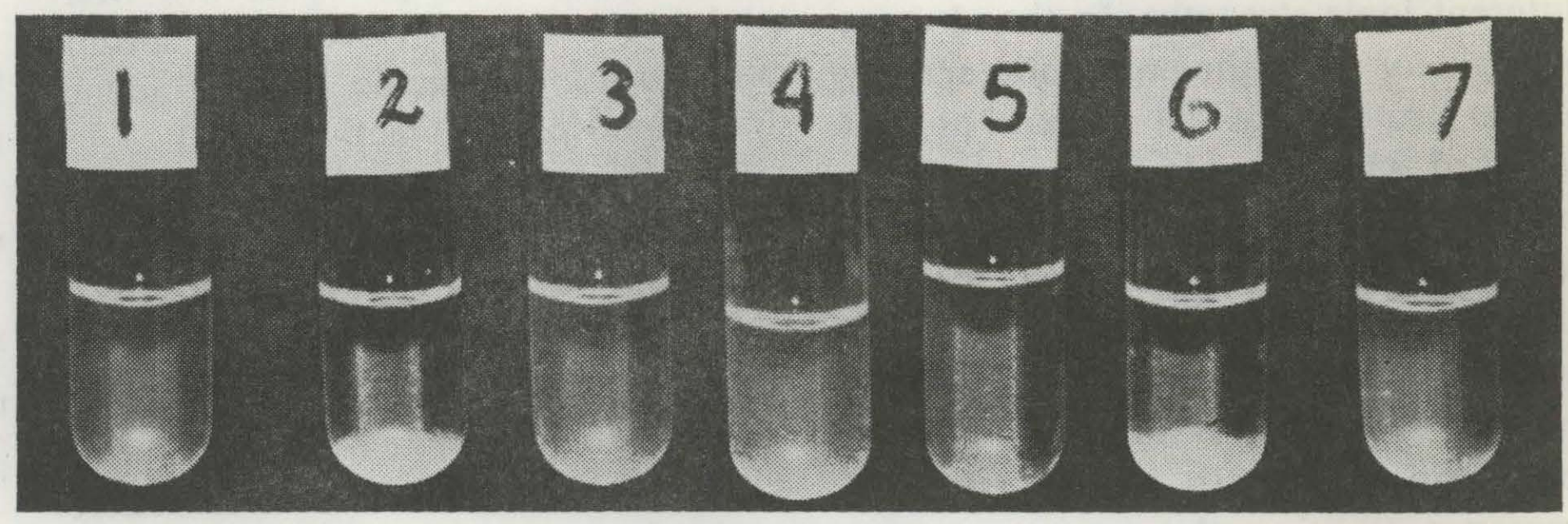

Fig. 1. Superprecipitation of protein isolated from whole brain of the rat and the effect of inhibitors. Each tube contained $0.25 \mathrm{mg}$ of protein in $0.1 \mathrm{M} \mathrm{KCl}$ and tris- $\mathrm{HCl}$ buffer, $p \mathrm{H} 7.2$ (0.001 mole/liter); (1) no $\mathrm{Mg}^{2+}$ or ATP; (2) $\mathrm{Mg}^{2+}$ and ATP; (3) $\mathrm{Mg}^{2+}$, no ATP; (4) no $\mathrm{Mg}^{2+}$ and ATP; (5) $\mathrm{Mg}^{2+}$, ATP, and Mersalyl (10 $\left.0^{-3} \mathrm{~mole} / \mathrm{liter}\right)$; (6) $\mathrm{Mg}^{2+}$, ATP, and ouabain $\left(10^{-4} \mathrm{~mole} /\right.$ liter $)$; (7) $\mathrm{Mg}^{2+}$, ATP, and $p$-chloromercuribenzoate $\left(10^{-2} \mathrm{~mole} /\right.$ liter $)$. Final concentration of $\mathrm{Mg}^{2+}, 3 \times 10^{-3} \mathrm{~mole} / \mathrm{liter}$; of ATP, $4 \times 10^{-3} \mathrm{~mole} /$ liter. Incubated at $37^{\circ} \mathrm{C}$ for 5 minutes.

Table 1. Effect of ionic concentration on $\mathrm{Mg}^{2+}$ or $\mathrm{Ca}^{2+}$-activated adenosine triphosphatase isolated from whole brain of rat and cat. The assay mixture contained $0.2 \mathrm{mg}$ of protein per milliliter, $5 \times 10^{-4}$ mole of ATP per liter, and $10^{-3}$ mole of $\mathrm{Mg}^{2+}, \mathrm{Ca}^{2+}$, or both per liter; and $0.05 \mathrm{M}$ imidazole- $\mathrm{HCl}$ buffer $[p \mathrm{H} 6.8$ (rat) or $p \mathrm{H} 7.6$ (cat)]. Mixtures were incubated at $37^{\circ} \mathrm{C}$ for 30 minutes. The results are the averages of duplicate determinations of micrograms of $P_{1}$ released per milligram of protein per 30 minutes. In the absence of $\mathrm{Ca}^{2+}$ and $\mathrm{Mg}^{2+}$ the values were less than $1 \mu \mathrm{g}$ of $\mathrm{P}_{\mathrm{i}}$ liberated.

\begin{tabular}{|c|c|c|c|c|}
\hline \multirow{2}{*}{$\begin{array}{l}\text { Activating } \\
\text { ion }\end{array}$} & \multicolumn{4}{|c|}{$\mathrm{KCl}$ (mole/liter) } \\
\hline & 0.03 & 0.1 & 0.3 & 0.6 \\
\hline \multicolumn{5}{|c|}{ Rat } \\
\hline $\mathrm{Mg}^{2+}$ & 12.6 & 12.0 & 6.2 & 2.9 \\
\hline $\mathrm{Ca}^{2+}$ & 8.2 & 5.1 & 6.5 & 6.5 \\
\hline $\mathrm{Mg}^{2+}+\mathrm{Ca}^{2+}$ & 9.6 & 7.3 & 6.0 & 2.6 \\
\hline \multicolumn{5}{|c|}{ Cat } \\
\hline $\mathrm{Mg}^{2+}$ & 11.9 & & 16.1 & 12.1 . \\
\hline $\mathrm{Ca}^{2+}$ & 9.0 & 16.4 & 17.7 & 15.4 \\
\hline $\mathrm{Mg}^{2+}+\mathrm{Ca}^{2+}$ & 9.9 & 14.2 & 13.0 & 8.9 \\
\hline
\end{tabular}


inhibited by ouabain $\left(10^{-4} \mathrm{~mole} / \mathrm{liter}\right)$. It was temperature-dependent, occurring much more rapidly at $37^{\circ} \mathrm{C}$ than at room temperature.

The protein exhibited adenosine triphosphatase activity. The released inorganic phosphate was determined by the Marsh procedure (10) adapted for the determination of $0.1 \mu \mathrm{g}$ of $\mathrm{P}_{\mathrm{i}}$. The $p \mathrm{H}$ optimum of the activity of the protein isolated from the rat was 6.8; that from the cat was 7.6. This was assayed in a medium containing in final concentration $0.2 M$ imidazole- $\mathrm{HCl}, 0.1 M$ $\mathrm{KCl}, 1 \times 10^{-3} M \mathrm{Mg}^{2+}$, and $5 \times 10^{-4} M$ ATP. The protein hydrolyzed approximately $10^{-2} \mu$ mole of ATP per minute per milligram of protein. The enzymatic activity was linear for the first $30 \mathrm{~min}$ utes and then gradually diminished over the next 30 minutes. This activity is approximately one-thirtieth that of actomyosin isolated from rabbit striated muscle, half that of smooth muscle (uterus) actomyosin, and twice that of contractile protein from sarcoma cells and blood platelets (11).

Table 1 shows the effect of $\mathrm{Mg}^{2+}$ and $\mathrm{Ca}^{2+}$ on the adenosine triphosphatase activity of the protein in media of different ionic strengths. In the absence of $\mathrm{Mg}^{2+}$ or $\mathrm{Ca}^{2+}$ the enzymatic activity of the protein was 10 percent of that achieved when $10^{-3} M \mathrm{Mg}^{2+}$ was present. In contrast to $\left(\mathrm{Na}^{+}+\mathrm{K}^{+}\right)$-activated adenosine triphosphatase (1), the hydrolysis of ATP was almost as good when $\mathrm{Ca}^{2+}\left(10^{-3}\right.$ mole/liter $)$ replaced the $\mathrm{Mg}^{2+}$ as the activating cation. Since the addition of both $\mathrm{Mg}^{2+}$ and $\mathrm{Ca}^{2+}$ were not additive, these ions are very probably stimulating the same enzyme and not two separate enzymes. The enzyme activity of the preparations was dependent upon the ionic strength and the cations of the medium. At low $\mathrm{KCl}$ concentration $(0.03$ mole/liter $) \mathrm{Mg}^{2+}$ activation was greatest, and at high $\mathrm{KCl}$ concentration $(0.6 \mathrm{~mole} / \mathrm{liter}) \mathrm{Ca}^{2+}$ activation was greatest; in the latter case
$\mathrm{Mg}^{2+}$ had an inhibitory effect. Actomyosin and myosin both have adenosine triphosphatase activity, and both are activated by $\mathrm{Ca}^{2+}$. An important difference is that myosin is inhibited by $\mathrm{Mg}^{2+}$ (12). At low ionic strength actomyosin predominates, whereas at high ionic strength the addition of ATP causes dissociation of actomyosin and the appearance of myosin adenosine triphosphatase characteristics (13). Our data are in general accord with these observations. It is very likely that the preparations contain "actin," "myosin," and "actomyosin." The data suggest that the rat preparation more closely resembles the actomyosin of muscle.

The adenosine triphosphatase activity of the proteins was inhibited in a fashion similar to that observed with superprecipitation. Mersalyl $\left(2.5 \times 10^{-4}\right.$ mole/liter) reduced the enzyme activity of the protein approximately 80 percent; p-chloromercuribenzoate $\left(2.5 \times 10^{-2}\right.$ mole/liter) reduced the enzyme activity to less than 5 percent. Ouabain in a concentration $\left(10^{-4} \mathrm{~mole} /\right.$ liter $)$ effective against the $\left(\mathrm{Na}^{+}+\mathrm{K}^{+}\right)$-activated enzyme (1) had only a slight inhibitory effect (approximately 5 percent). Mersalyl has been described as a specific inhibitor of contractile protein adenosine triphosphatase activity (14).

The evidence indicates that at least part of the $\mathrm{Mg}^{2+}$ or $\mathrm{Ca}^{2+}$-activated adenosine triphosphatase activity in brain is due to a contractile protein similar to actomyosin.

Contractile proteins in cells may serve a universal function as in cell reproduction (15) or a specific function as in striated and smooth muscle contraction (16), clot retraction (11), or cell movement (15). In liver mitochondria it has been described as functioning in the regulation of glycolysis and energy metabolism (17). It has been suggested that in nervous tissue it is associated with changes in permeability during excitation $(2,3)$ and in control of acetylcholine storage and release (4). The basis for all its functions is very probably conformational changes transmitted to membranes.

S. PuszKin S. BERL

Columbia University,

College of Physicians and Surgeons,

New York 10032

Mount Sinai School of Medicine,

New York

D. D. Clarke

Fordham University, Bronx, New York

\section{References}

1. J. C. Skou, Physiol. Rev. 45, 597 (1965).

2. B. Libet, Fed. Proc. 7, 72 (1948).

3. K. Bowler and C. J. Duncan, Nature 211, 642 (1966); J. Cell Physiol. 70, 121 (1967).

4. M. Germain and P. Proulx, Biochem. Pharmacol. 14, 1815 (1965); K. Kadota, S. Mori, R. Imaizumi, J. Biochem. 61, 424 (1967).

5. A. Szent-Györgyi, Chemistry of Muscle Contraction (Academic Press, New York, 1951), p. 151.

6. O. H. Lowry, N. J. Rosebrough, A. L. Farr, R. J. Randall, J. Biol. Chem. 193, 265 (1951).

7. E. Layne, in Methods in Enzymology, S. P. Colowick and N. O. Kaplan, Eds. (Academic Press, New York, 1957), vol. 3, p. 447.

8. A. Szent-Györgyi, Chemistry of Muscle Contraction (Academic Press, New York, 1951), p. 34.

9. Mersalyl (Salyrgan) sodium salt of $o-[(3-h y-$ droxymercuri-2-methoxypropyl)carbamyl]phenoxyacetic acid.

10. B. B. Marsh, Biochim. Biophys. Acta 32, 357 (1959).

11. M. Bettex-Galland and E. F. Lüscher, in Advances in Protein Chemistry (Academic Press, New York, 1960), vol. 20, p. 1.

12. D. M. Needham, in Structure and Function of Muscle, G. H. Bourne, Ed. (Academic Press, New York, 1960), vol. 2, p. 72 .

13. W. Hasselbach, Z. Naturforsch. 76, 163 (1952).

14. H. Hoffman-Berling, Biochim. Biophys. Acta 19, 453 (1956).

15. - , in Comparative Biochemistry, $\mathbf{M}$. Florkin and H. S. Mason, Eds. (Academic Press, New York, 1960), vol. 2, p. 341.

16. S. V. Perry, ibid., p. 245.

17. S. A. Neifakh, J. A. Avramov. V. S. Gaitskhoki, T. B. Kazakova, N. K. Monakhov, V. S. Repin, V. V. Turovski, I. M. Vassiletz, Biochim. Biophys. Acta 100, 329 (1965).

18. Supported in part by PHS grant NB-04064; PHS career development award K3-NB-5117 (S.B.); Cerebral Palsy Education and Research Foundation grant R-206-66; and by the Clinical Research Center for Parkinson's and Allied Diseases (PHS grant NB-05184) and the Parkinson Information Center under PHS contract PH 436454.

17 May 1968 